\title{
ECONOMY
}

\section{GENDER DISCRIMINATION ISSUES IN THE LABOUR MARKET OF ARMENIA}

\author{
Lusine Karapetyan, associate professor, $\mathrm{PhD}$ in Economics \\ Chair of Labour Economics of Armenian State University of Economics, \\ Yerevan, Republic of Armenia.
}

DOI: https://doi.org/10.31435/rsglobal_ws/30082018/6053

\begin{abstract}
ARTICLE INFO
Received: 14 July 2018

Accepted: 24 August 2018

Published: 30 August 2018

\section{KEYWORDS}

labour market, gender, wages, employed, inequality.

ABSTRACT

Unfortunately, gender stereotypes still remain in the 21st century and require social, cultural, traditional and political radical changes. Often, this inequality is conditioned not by the laws set by the state, but by the so-called "unwritten" laws that are subject to "compulsory enforcement" and have stronger grounds than supreme legislation. Gender inequality is particularly obvious in low-income countries and extremely poor households. The aim of the research is to study and analyze gender discrimination, management and decision-making processes related to education, employment, unemployment, pension security and women's work motivation in labour market policies in the Republic of Armenia. The information of this study was obtained through various secondary sources like statistic reports, websites, besides has been used qualitative research method in particular, the depth interview method.
\end{abstract}

Citation: Lusine Karapetyan. (2018) Gender Discrimination Issues in the Labour Market of Armenia. World Science. 8(36), Vol.1. doi: 10.31435/rsglobal_ws/30082018/6053

Copyright: (C) 2018 Lusine Karapetyan. This is an open-access article distributed under the terms of the Creative Commons Attribution License (CC BY). The use, distribution or reproduction in other forums is permitted, provided the original author(s) or licensor are credited and that the original publication in this journal is cited, in accordance with accepted academic practice. No use, distribution or reproduction is permitted which does not comply with these terms.

Introduction. There are demographically stable characteristics, according to which the population is divided into different groups. The most stable differences in these groups are related to gender descriptions- gender differences. Changes in economic and political systems bring forward great opportunities and at the same time serious challenges and uncertainties in each individual's life. The most obvious manifestation of gender discrimination against women is the attitude towards them in the labour market, with several types of discrimination, such as wages, labour conditions, hiring and dismissal, promotion, and so on.

Gender relations define gender-based discrimination and certain areas of activity for women and men. They cause to gender-based segmentation of employment in the labour market and gender inequality in households. That is, male or female, people immediately appear in the centre of already formed relations. Due to the employment in the household, women spend more time in unpaid branches than men, women are less likely to invest in human capital, but even having equal capabilities and professional competence in the labour market women face discriminatory attitude. That is to say, discrimination in the labour market can be characterized as unequal opportunities for workers, characterized by equal working efficiency, and unequal attitude from the state. In different economies employees with equal performance and same qualifications are often paid in different amounts. Starting the end of the 20th century according to a number of economists, including the Ingrid Rima, Barbara Bergman, the difference between salaries of men and women are mainly based on the factors for job offers $[1,8]$. According to Bergman in the basis of discrimination in the labor market lies the hypothesis of concentrating or exceeding the workforce in certain branches, spheres or 
occupations. That is, a significant proportion of the gender based remuneration is indeed conditioned by the choice of occupation. As far as the average level of salary is lower in case of occupations with women workforce compared with the average level of salary in case of occupations with men workforce [4]. The problem of gender inequality in wages is reflected in a number of countries in the world trying to find ways to eliminate or at least reduce these differences.

Researches show that in any country women are dominant in households, that's why they have fewer opportunities to improve their qualifications, knowledge and acquire work skills. Women make less financial investments in improvements of qualifications, because their career, as opposed to men, lasts a shorter period of time as a result of possible breaks while being employed. Besides, employers are not inclined to invest in the improvement of women's qualification either, as they can not afford the expected outcome. There are also unequal opportunities for hiring, mainly conditioned by sex, age, national, racial, and sometimes even religious and political reasons. Women often face discrimination in service promotion, that is, obsticles in being given resonsible positions. Employers prefer to hire men, reasoning that women are more likely to be late for work, besides they are more demanding in terms of work conditions, social package, and also do not want to do overtime work [7].

The legislative equality of women and men's rights in the Republic of Armenia is guaranteed by its Constitution. Since its independence, the Republic of Armenia has implemented a policy of providing equal rights for women and men by ratifing a number of international documents. In 1993, the UN Convention on the Elimination of All Forms of Discrimination against Women was ratified, in 2007- the United Nations Convention on Women's Political Rights, in 1995- adopted the assignments suggested by the Fourth World Women's Conference in Beijing. In 2004, the revised European Social Charter was ratified, in accordance with which the rights of equal opportunities and equal attitude in the field of sexual discrimination and protection of the rights of working women, the right to fair remuneration have been adopted. At the same time, the employer's notification of the dismissal of a woman is considered illegal during her pregnancy as well as till the end of her maternity leave. According to the Labour Code of the Republic of Armenia, the employment contract can not be terminated with pregnant women, for one month after officially informing the employer about pregnancy, as well as with those who are to take care of a child under one year. Besides, the legal basis for the termination of the employment contract made according to the RA Labour Code cannot be the gender, race, nationality, language, origin, citizenship, social status, religion, beliefs, marital and family status, membership of political parties or non-governmental organizations. From the point of view of the solution of gender issues the adoption of 2004-2010 national program, which was meant to improve the status of women and increase their role in the society, was important. In 2010 the Government has approved the Gender Policy Concept of the Republic of Armenia, in 2013 the RA Law on Equal Rights and Equal Opportunities for Women and Men was adopted. And the next important document is "2017-2021 Strategic Program of The RA Gender Equality Policy".

In 2018 after velvet revolution in the Republic of Armenia the involvement of women in the public-political life has been significantly increased. Thus, two women have been appointed as mayors.

Result and Discussion: To reveal gender discrimination issues it is important to present the main indexes of gender distribution statistics in Armenia, their movement and analysis.

Table 1. The main indicators characterizing the labor market by gender 2002-2016 (in\%)

\begin{tabular}{|l|c|c|c|c|c|c|c|c|c|c|c|c|c|c|}
\hline & \multicolumn{2}{|c|}{2002} & \multicolumn{2}{c|}{2007} & \multicolumn{2}{c|}{2012} & \multicolumn{2}{c|}{2013} & \multicolumn{2}{|c|}{2014} & \multicolumn{2}{|c|}{2015} & \multicolumn{2}{|c|}{2016} \\
\cline { 2 - 14 } & $\mathrm{W}$ & $\mathrm{M}$ & $\mathrm{W}$ & $\mathrm{M}$ & $\mathrm{W}$ & $\mathrm{M}$ & $\mathrm{W}$ & $\mathrm{M}$ & $\mathrm{W}$ & $\mathrm{M}$ & $\mathrm{W}$ & $\mathrm{M}$ & $\mathrm{W}$ & $\mathrm{M}$ \\
\hline 1 & 2 & 3 & 4 & 5 & 6 & 7 & 8 & 9 & 10 & 11 & 12 & 13 & 14 & 15 \\
\hline $\begin{array}{l}\text { Resident } \\
\text { population }\end{array}$ & 51.9 & 48.1 & 51.7 & 48.3 & 52.0 & 48.0 & 51.9 & 48.1 & 52.2 & 47.8 & 52.2 & 47.8 & 52.3 & 47.7 \\
\hline $\begin{array}{l}\text { Households by } \\
\text { sex of the head } \\
\text { of hosehold }\end{array}$ & 28.2 & 71.8 & 31.3 & 68.7 & 32.2 & 67.8 & 32.8 & 67.2 & 32.9 & 67.1 & 34 & 66 & 33 & 67 \\
\hline $\begin{array}{l}\text { Labour resource } \\
\text { by education, } \\
\text { including }\end{array}$ & - & - & - & - & 55.6 & 44.4 & 55.5 & 44.5 & 56.1 & 43.9 & 55.4 & 44.6 & 55 & 45 \\
\hline $\begin{array}{l}\text { Higher, } \\
\text { postgraduate }\end{array}$ & - & - & - & - & 57 & 43 & 57.6 & 42.4 & 58.7 & 41.3 & 57 & 43 & 57 & 43 \\
\hline
\end{tabular}


Continuation of Table 1

\begin{tabular}{|l|l|l|l|l|l|l|l|l|l|l|l|l|l|l|}
\hline \multicolumn{1}{|c|}{1} & 2 & 3 & 4 & 5 & 6 & 7 & 8 & 9 & 10 & 11 & 12 & 13 & 14 & 15 \\
\hline $\begin{array}{l}\text { Secondary } \\
\text { professional, } \\
\text { incomplete } \\
\text { higher }\end{array}$ & - & - & - & - & 62.3 & 37.7 & 62.9 & 37.1 & 65.8 & 34.2 & 66.5 & 33.5 & 66.5 & 33.5 \\
\hline $\begin{array}{l}\text { Initial } \\
\text { (technical) }\end{array}$ & - & - & - & - & 43.7 & 56.3 & 44.4 & 55.6 & 38.2 & 61.8 & 33.1 & 66.9 & 33 & 67 \\
\hline $\begin{array}{l}\text { Complete } \\
\text { general } \\
\text { secondary }\end{array}$ & - & - & - & - & 53.6 & 46.4 & 53.6 & 46.4 & 52.5 & 47.5 & 52.7 & 47.3 & 53 & 47 \\
\hline Basic general & - & - & - & - & 48.6 & 51.4 & 44.9 & 55.1 & 50.1 & 49.9 & 44.6 & 55.4 & 45 & 55 \\
\hline $\begin{array}{l}\text { Primary, } \\
\text { incomplete } \\
\text { primary }\end{array}$ & - & - & - & - & 53.8 & 46.2 & 44.8 & 55.2 & 52.4 & 47.6 & 49.3 & 50.7 & 49.3 & 50.7 \\
\hline $\begin{array}{l}\text { Economically } \\
\text { activew } \\
\text { population }\end{array}$ & 47 & 53 & 49 & 51 & 49 & 51 & 49 & 51 & 49 & 51 & 49 & 51 & 49 & 51 \\
\hline $\begin{array}{l}\text { Employed } \\
\text { population }\end{array}$ & 44 & 56 & 45 & 55 & 48 & 52 & 48 & 52 & 48 & 52 & 48 & 52 & 47. & 52. \\
\hline $\begin{array}{l}\text { Unemployed } \\
\text { population }\end{array}$ & 53 & 47 & 61 & 39 & 51 & 49 & 55 & 45 & 54 & 46 & 51 & 49 & 51 & 49 \\
\hline $\begin{array}{l}\text { Population not } \\
\text { economically } \\
\text { active }\end{array}$ & 75 & 25 & 67 & 33 & 67 & 33 & 67 & 33 & 68 & 32 & 67 & 33 & 67 & 33 \\
\hline
\end{tabular}

The calculation was made by the author based on the NSS data

Table 1 shows that in 2002-2016, there was almost no change in the proportion of women in the population of the RA and in 2016 the number of women increased by 0.4 percentage points compared with 2002 and was 52.3\%. The analysis of the households' according to their indicators of dominant sex shows that, compared to 2002 in 2016 the proportion of women has increased by 14.8 percentage points and amounted to $33 \%$, which is conditioned by the increase in divorce, mortality and emigration. About 55\% of working resources are women and 45\% are men. In 2002-2016 according to the data, women's share in higher education and postgraduate education is higher than that of men (average 57.6\%) and in secondary professional, incomplete higher education (women average $64.4 \%$ ). And the higher is the educational level of the woman, the higher is the cost of her time spent in the household. In 2016, compared with 2002, the economically active population share of women increased by 4 percentage points reaching 51\%, while in the economically not active population, women outnumber men twice. Of course, in comparison with 2002, in 2016 this index decreased by 8 percentage points, but still remains high- 67\%, we think all these are conditioned by family circumstances, lack of hope for finding a job, etc. In 2016 gender gap in activity rates of women and men is 26.4 percent. Gender gap is especially high in the 25 to 34 age groups (40\%), mainly due to engagement of women in family responsibilities (pregnancy, childbirth, child care, etc.). Gender gaps especially high in the 25 to 49 age groups (64.9\%-71.5\%), mainly due to engagement of women in family responsibilities. In contrast, among youth of $15-24$ age groups $12.7 \%$ gender gap in inactivity rate is due to the massive involvement of youth in education, regardless of sex.

In 2016, about $51 \%$ of the unemployed were women and $49 \%$ were men. Women's unemployment has been high especially in 2007, making up 61\% of the unemployed. And in the number of employed, men are more than women by 3 percentage points.

Women's orientation in the labour market is one of the key factors that affects the choice of the job, as well as the salary and consequently the income level. In the RA employment studies carried out according to economic branches have shown that working women are concentrated only in certain sectors of the economy. In this case gender differences in salaries are conditioned by the professional or sectoral disproportionate distribution of women and men (Table 2). 
Table 2. Employed Population By Groups Of Economic Activities 2011-2016 (\%)

\begin{tabular}{|l|c|c|c|c|c|c|c|c|c|c|c|c|c|}
\hline & \multicolumn{2}{|c|}{2011} & \multicolumn{2}{c|}{2012} & \multicolumn{2}{c|}{2013} & \multicolumn{2}{c|}{2014} & \multicolumn{2}{|c|}{2015} & \multicolumn{2}{c|}{2016} \\
\cline { 2 - 14 } & W & M & W & M & W & M & W & M & W & M & W & M \\
\hline Employed, total & 48 & 52 & 48 & 52 & 48 & 52 & 48 & 52 & 48 & 52 & 48 & 52 \\
\hline Agriculture & 56 & 44 & 57 & 43 & 59 & 41 & 56 & 44 & 54 & 46 & 54 & 46 \\
\hline Manufacturing & 27 & 73 & 30 & 70 & 26 & 74 & 32 & 68 & 30 & 70 & 30 & 70 \\
\hline Construction & 2 & 98 & 3 & 97 & 4 & 96 & 5 & 95 & 4 & 96 & 4 & 96 \\
\hline $\begin{array}{l}\text { Trade, repair, accommodation } \\
\text { and food service activities }\end{array}$ & 46 & 54 & 47 & 53 & 47 & 53 & 44 & 56 & 44 & 56 & 44 & 56 \\
\hline $\begin{array}{l}\text { Transportation and storage, } \\
\text { information and communication }\end{array}$ & 20 & 80 & 24 & 76 & 17 & 83 & 22 & 78 & 22 & 78 & 22 & 78 \\
\hline $\begin{array}{l}\text { Financial, real estate, } \\
\text { professional, scientifi c, } \\
\text { technical, administrative and } \\
\text { support activity }\end{array}$ & 41 & 59 & 40 & 60 & 44 & 56 & 49 & 51 & 41 & 59 & 41 & 59 \\
\hline $\begin{array}{l}\text { Public administration, } \\
\text { education, human health and } \\
\text { social work }\end{array}$ & 66 & 34 & 65 & 35 & 62 & 38 & 62 & 38 & 60 & 40 & 60 & 40 \\
\hline Other services & 51 & 49 & 55 & 44 & 55 & 45 & 57 & 43 & 52 & 48 & 52 & 48 \\
\hline
\end{tabular}

The calculation was made by the author based on the NSS data

The data in Table 2 show that in 2011-2016 in Armenia men were constituting the majority in industry, construction, transportation, storage economy, information and communication. The men's share was also high in financial, real estate, professional, scientific-technical, administrative and other supporting activities, and this is where the average monthly nominal wage is the highest of the wages of other sectors of the economy. Quantitative assessment of discrimination in the labour market is challenging. To give the quantitative assessment of the professional discrimination level between men and women in Armenia in 2016, we will use the Dissimilation Index or Discrimination Index (Duncan's Index) [2]. It shows what percentage of women in a given group, should change their profession or occupation, so that the structure of employment in both groups become equal. Table 3 shows the employed by occupation groups according to the RA National Statistical Service, and it is followed by our calculations.

Table 3. Employed Population by Occupation Groups, 2016 (proportion of each sex to employed population of the relevant group, \%)

\begin{tabular}{|l|c|c|}
\hline & Men & Women \\
\hline Legislators, senior officials, managers & 71 & 29 \\
\hline Professionals & 41 & 59 \\
\hline Technicians professionals & 42 & 58 \\
\hline Clerks & 38 & 62 \\
\hline Service and sales workers & 47 & 53 \\
\hline Skilled agricultural; Craft workers, Operators \& assemblers & 58 & 42 \\
\hline Elementary occupations & 53 & 47 \\
\hline
\end{tabular}

Source: NSS of the RA

In this case, the discrimination index will be:

$\mathrm{S}=[71-29] / 2+[41-59] / 2+[42-58] / 2+[38-62] / 2+[47-53] / 2+[58-42] / 2+[53-47] / 2=64$

However, it should be noted that professional segregations are not always a result of discrimination because there are professions and occupations which are extremely harmful for women of reproductive age. Here the national traditions, customs and family preferences are taken into account. Men holding senior positions exceed women 2.4 times. Also men are involved in jobs requiring high and middle qualifications more often than women.

The next important type of labour market discrimination in the Republic of Armenia is the gender difference in wages, which is quite high. It should be noted that this difference is not entirely 
due to gender-based discrimination against women. There are a number of factors that affect women's wage levels. In Armenia women's employment spheres are considered to be health, education, and culture, while men's employment spheres include finances, insurance, information and communication, as well as construction.

Table 4. Average Monthly Nominal Wages by Types of Economic Activity, 2007-2016 (W/M, \%)

\begin{tabular}{|l|c|c|c|c|c|c|c|}
\hline & 2007 & 2011 & 2012 & 2013 & 2014 & 2015 & 2016 \\
\cline { 2 - 8 } & W/M & W/M & W/M & W/M & W/M & W/M & W/M \\
\hline Agriculture, forestry and fishing & - & 80.4 & 91.4 & 100.2 & 90.0 & 94.9 & 90.6 \\
\hline Mining and quarrying & - & 48.0 & 47.8 & 49.4 & 53.6 & 62.6 & 61.6 \\
\hline Manufacturing & 61.8 & 61.7 & 66.2 & 62.9 & 65.5 & 67.6 & 66.9 \\
\hline $\begin{array}{l}\text { Electricity, gas, steam and air } \\
\text { conditioning supply }\end{array}$ & - & 78.3 & 80.8 & 83.9 & 87.0 & 87.3 & 95.1 \\
\hline $\begin{array}{l}\text { Water supply; sewerage, waste } \\
\text { management and remediation } \\
\text { activities }\end{array}$ & - & 77.6 & 80.1 & 88.9 & 87.3 & 82.8 & 82.7 \\
\hline Construction & 76.3 & 77.2 & 78.5 & 75.9 & 76.5 & 75.8 & 90.0 \\
\hline $\begin{array}{l}\text { Wholesale and retail trade; } \\
\text { repair of motor vehicles and } \\
\text { motorcycles }\end{array}$ & - & 74.9 & 76.5 & 77.6 & 78.5 & 78.8 & 78.5 \\
\hline Transportation and storage & - & 72.5 & 80.9 & 72.9 & 74.6 & 74.7 & 73.6 \\
\hline $\begin{array}{l}\text { Accommodation and food } \\
\text { service activities }\end{array}$ & - & 96.4 & 67.3 & 88.0 & 87.3 & 88.8 & 90.2 \\
\hline Information and communication & - & 78.2 & 74.2 & 75.4 & 72.3 & 73.2 & 61.6 \\
\hline $\begin{array}{l}\text { Financial and insurance } \\
\text { activities }\end{array}$ & - & 62.0 & 58.9 & 58.2 & 59.6 & 57.3 & 55.6 \\
\hline Real estate activities & - & 79.7 & 84.4 & 81.4 & 81.3 & 86.6 & 79.8 \\
\hline $\begin{array}{l}\text { Professional, scientific and } \\
\text { technical activities }\end{array}$ & - & 65.8 & 71.4 & 78.8 & 74.8 & 74.9 & 76.8 \\
\hline $\begin{array}{l}\text { Administrative and support } \\
\text { service activities }\end{array}$ & - & 66.2 & 73.4 & 74.3 & 77.5 & 79.2 & 74.7 \\
\hline $\begin{array}{l}\text { Public administration and } \\
\text { defence; compulsory social } \\
\text { security }\end{array}$ & - & 70.8 & 73.2 & 74.5 & 79.9 & 82.5 & 81.9 \\
\hline Education & 83.4 & 81.3 & 80.8 & 82.3 & 80.0 & 80.6 & 80.7 \\
\hline $\begin{array}{l}\text { Human health and social work } \\
\text { activities }\end{array}$ & 71.9 & 64.9 & 65.0 & 67.2 & 62.4 & 67.0 & 65.0 \\
\hline $\begin{array}{l}\text { Arts, entertainment and } \\
\text { recreation }\end{array}$ & - & 79.9 & 81.8 & 85.9 & 80.8 & 86.9 & 90.4 \\
\hline Other service activities & - & 71.8 & 84.8 & 85.9 & 83.1 & 78.2 & 74.2 \\
\hline Total & 60.0 & 64.7 & 63.7 & 65.6 & 65.9 & 66.5 & 66.4 \\
\hline
\end{tabular}

Source: NSS of the RA

According to the analysis of men's and women's average monthly salaries in 19 types of economic activities in the Republic of Armenia, the highest rate of salary difference between men and women was recorded in 2016 in financial and insurance activities. Thus, women's average earnings constituted $55.6 \%$ of men's earnings or gender fracture of remuneration constituted $44.4 \%$, moreover it has increased by 6.4 percentage points compared to 2011. Gender fracture in remuneration is also high in mining and quarrying, manufacturing, human health and social work activities $-35.8 \%$ on average. The lowest gender fracture in remuneration was recorded in electricity, gas, steam and air, 4.9, agriculture, forestry and fishing $-9.4 \%$ in 2016. And in 2013 women's average wage was even higher than men's average wage by $0.2 \%$.

Difference of average nominal wages (earnings) of women and men decreased by 7.2 percentage points over the last ten years. In 2016 the women's earnings amounted to $66.4 \%$ of men's earnings, e.g. gender pay gap is amounted $33.6 \%$. 
According to the Labour Code of the Republic of Armenia, the duration of normal working hours is 8 hours per day and should not exceed 40 hours per week.

The study of the average weekly hours according to he types of employment and major groups of employment types shows that the average weekly hours spent by women in formal employment in 2016 was 39.1 hours, and men's- 45.6 hours, as for non-formal employment, women spent 27.1 hours, and men - 36.2 hours.

The men work more than women, regardless of economic activity sector and the nature of the legal relationship of work.

Since 2006, World Economic Forum analysts have evaluated the Global Gender Gap Index (GGGI) in a number of countries around the world. The goal of GGGI calculation is to look for ways to overcome gender inequality.

In 2017, the World Economic Forum's report contained data from 144 countries regarding inequality between women's and men's income. According to the survey results, no country has achieved full legal equality.

Table 5. Gender Gap Index in Armenia in 2008-2017

\begin{tabular}{|l|l|l|l|l|l|l|}
\hline & 2008 & 2010 & 2012 & 2014 & 2016 & 2017 \\
\hline $\begin{array}{l}\text { GGI, } \\
\text { Rankings by subindex }\end{array}$ & 78 & 84 & 92 & 103 & 102 & 97 \\
\hline $\begin{array}{l}\text { Economic participation and } \\
\text { opportunity }\end{array}$ & 36 & 59 & 76 & 82 & 69 & 71 \\
\hline Educational attainment & 29 & 26 & 25 & 31 & 27 & 42 \\
\hline Health and survival & 130 & 130 & 130 & 142 & 143 & 143 \\
\hline Political empowerment & 118 & 106 & 114 & 123 & 125 & 111 \\
\hline
\end{tabular}

Source: GGG Report

According to GGGI, Armenia was $97^{\text {th }}$ among 144 countries in 2017. Moreover, it was the $71^{\text {th }}$ due to economic participation and opportunity, the $42^{\text {nd }}$ due to educational attainment, $143^{\text {th }}$-health and survival and the $111^{\text {th }}$ - political emprowerment. In 2008, Armenia was the $78^{\text {th }}$ out of 130 countries according to GGGI. According to 2016 Human Development Reports, Armenia was the $84^{\text {th }}$ out of 188 countries in the Gender Development Index and in Gender Inequality Index Armenia was the $61^{\text {st }}$.

At present, in Armenia as in a number of countries around the globe pension reforms are being implemented, with the cumulative pension component being invested, which means that in the case of this model, the size of a person's future pension will depend on the amount of his salary, donations and the incomes of their investments.

Consequently, if differences between women's and men's salaries are not eliminated or reduced during the working age, they will also turn into "pension gender differences" in the cumulative pension system.

In addition, a qualitative research has been carried out, in particular, the depth interview method, to find out the expert opinion, his approaches, attitudes about gender issues in the labour market, which will provide deep and substantiated data.

In the in-depth interview, unequal remuneration, education, career orientation issues, as well as low levels of women's involvement in senior positions, and the issues of discrimination against women by employers in the hiring process were singled out and the following opinion-suggestions were received.

The causes of gender discrimination and unequal remuneration in Armenia are mainly related to women's and men's professional separation. The division of economic sectors and types of activity between men and women was carried out even in Soviet times. Moreover, in the wage policy, preference was given to heavy and mining industries and construction, traditionally described by the use of manpower. On the official scale as well preference was given to men, which provides them with higher wages.

Although there are no officially imposed restrictions on women, however, women have limited access to a career level than the level established by gender discrimination. This means that professional advancement in managing others and unifying their efforts, bearing responsibility for the final result and overcoming difficulties are motivating factors for men. The slower rates of women's professional advancement as compared with men are conditioned by double burden (family and professional work). Unlike men, women are mostly inclined to choose family and children than professional advancement. 
Conclusions. The studies above prove that gender differences in salaries are rather high in Armenia. Therefore, it is necessary to take measures to eliminate these differences or at least to reduce them. The majority of women often works part-time or with shorter working schedules, and therefore earn less than men. Moreover, in those sectors where women are mostly engaged, the salary level is noticeably lower. Women prefer to work in the public sector as their working hours are fixed, the job is stable, but the salary in the public sector is lower. In the Republic of Armenia there are discriminations in hiring the empoyees, including age discrimination, since employers mostly hire young people (20 to 30 ).

There is practically no gender discrimination in the field of education in the Republic of Armenia. Women outnumber men in higher and secondary vocational education. In addition to the above mentioned, hard social and economic conditions in the country also affect the choice of women's occupations. A woman is often ready to work even in low-qualification jobs, with low salaries only to provide the family with additional financial support, and does not allocate time and money on self-education and qualification upgrading.

The enforcement of the legislation to equal rights cannot solve all the issues of discrimination in the labour market, since discrimination is a complex phenomenon, the cause and effect of which are replaced during the time. The state should take the following steps:

- reduction of gender differences in employment;

- development of programs to reduce gender fracture in remuneration; promotion.

- creation of necessary conditions for women's career advancement and employment

\section{REFERENCES}

1. Barbara B. (1971). The Effect of White Incomes on Discrimination in Employment: Journal of Polotical Economy 79, March/ April, 249-313.

2. Duncan, Otis Dudley; Duncan, Beverly (1955-01-01). "A Methodological Analysis of Segregation Indexes". American Sociological Review. 20 (2): 210-217.

3. Global Gender Gap Report 2017, World Economic Forum, weforum.org.

4. Global Employment Trends, ILO, Geneva, 2016.

5. Hovhannisyan G. (2004). Gender and Economics, 92-102.

6. Human Development Report 2016, UNDP, New York, 2016.

7. Kaufman B. (2007). The Economics of Labour Markets, Fort Worth: Dryden Press.

8. Melqumyan A. (2017). Labour Market, 241-261.

9. Rima I. (1991). Labour Markets in a Global Econmy, 271-272.

10. Women at work, Trends 2016, ILO, Geneva, 2016.

11. Women and men in Armenia, 2017, NSS of RA.

12. http://www.armstat.am/.

13. http://parliament.am/

14. www.ilo.org./ 